\title{
Emigration Agents and the Agency of the Urban Press: Approaches to Transatlantic Migration in Hungary, 1880s-1914
}

\begin{abstract}
This article argues the importance of the urban press in shaping public opinion about transatlantic migration using the representation of emigration agents and agencies in the Hungarian press in the late nineteenth and early twentieth century. This also draws light to the importance of Budapest not only as a critical hub of emigration movements in terms of administration, transportation and information network directed and controlled overseas emigration, but also as an agent of communication: the urban press, inseparable from the constantly transforming urban space, was a key agent in the transmission of knowledge and forming public opinion about the emigration question that was in the centre of political, social and cultural discourse in this period.
\end{abstract}

\section{Keywords}

transatlantic migration, urban press, emigration agents, Budapest, Hungary, Habsburg Empire

\section{Introduction: Emigration in the Hungarian Press in the Late Nineteenth and Early Twentieth Century}

As the year 1887 was coming to a close, the Brasilian state council received a letter from a Hungarian railway worker Károly Botond living in Miskolc, an important mining and industrial town in Northeast Hungary. In the letter, which he sent to South America through the Brasilian consulate in Budapest, he inquires whether the reports of the 'more important Budapest newspapers' are indeed true, and 'the government of 
Brasil is in need of 5,000 emigrants'. He stressed that he would also like to know more about the conditions and types of work available in Brasil, as well as why exactly the Brasilian government is looking for Hungarians specifically. Nonetheless, if the conditions are favourable, he writes, a group of Hungarians would be willing set off on the journey. ${ }^{1}$

That Botond and his compatriots turned to the Brasilian government for information does not only illustrate that they were interested (or desperate) enough to contact the Brasilian state council directly; it also implies that they did not find locally available information - the most common sources being the press and emigration agents - sufficient or satisfactory. This is not even surprising, given how - in spite of the fact that the Brasilian government did, in fact, support immigration in the last third of the nineteenth century - public discourse in Hungary and the AustroHungarian Monarchy in general, as represented in the majority of the press, had a negative overtone in line with the increasing efforts of the government to control emigration by the end of the nineteenth and the early twentieth century especially. Emigration to Brazil was specifically discouraged: according to an 1899 newspaper report, Ignác Darányi, Minister of Agricultulture between 1895-1903 and 1906-1910, ordered that

'officials $[\ldots]$ do everything within their legal means to block emigration and act against emigration agents with all possible force of the law. The reason for this is that according to some consular reports, the large crowds of emigrants from Austria and Hungary who are now in Sao Paolo county in Brazil, are living in great poverty. Moreover, officials should inform the people about the poor conditions living abroad, and of the many problems that they could avoid by seeking employment at home.' ${ }^{2}$

\footnotetext{
${ }^{1}$ Ágnes Judit Szilágyi, 'Brazília a XIX. század végi magyar újságolvasók szemével: Kivándorlási propaganda és ellenpropaganda a korabeli sajtóban' [Brasil in the eyes of the readers of late-nineteenth century Hungarian newspapers: Emigration propaganda and anti-propaganda in the press], Sic Itur ad Astra: Fiatal történészek folyóirata 7:2-4 (1993): 60-66. The letter in the original German language, and in a Brasilian translation, can be found in Appendix 1, 64-65.

2 'Darányi miniszter a kivándorlas ellen' [Minister Darányi against emigration], Köztelek 9:45 (1899): 880-881. All translations are mine, unless otherwise indicated.
} 
It was not only the local conditions across the Atlantic that were used to dissuade prospective emigrants in the anti-emigration propaganda of the government, an important tool of which were the press and their reporting about the difficulties of the emigration process and its consequences. Much of pro-emigration propaganda came from the shipping companies, their representatives, and importantly, emigration agents whose primary aim was to sell as many tickets as possible - in some cases, even free tickets, such as the ones provided by the pro-immigration Brazilian government. ${ }^{3}$ Emigration agents thus often became the scapegoat of anti-emigration propaganda in the Habsburg Empire, and the Hungarian press had an important role in perpetuating the image of the emigration agent as 'new slaveholders' drawing away exploited human capital from their homeland and nation. ${ }^{4}$

This article argues the importance of the urban press in shaping public opinion about transatlantic migration using the representation of emigration agents and agencies in the Hungarian press in the late nineteenth and early twentieth century. This also draws light to the importance of Budapest not only as a critical hub of emigration movements in terms of administration, transportation and information

\footnotetext{
${ }^{3}$ Szilágyi, 'Brasil in the eyes of the readers of late-nineteenth century Hungarian newspapers', 60.

${ }^{4}$ Szilágyi, 'Brasil in the eyes of the readers of late-nineteenth century Hungarian newspapers', 60. The press often drew parallels between the situation of emigrants (especially to the Americas) and slavery: for instance, the Budapesti Hirlap repeatedly compares the activity of emigration agents to "slave trade" in articles such as 'Trefort a kivándorlás ellen' [Trefort against emigration], Budapesti Hírlap, 8:195 (15 July 1888): 2); 'A népszámlálás Ausztriában' [The census in Austria], Budapesti Hírlap 11:58 (28 February 1891): 9; 'Kivándorlók nyomora' [The destitution of emigrants], Budapesti Hírlap 16:87 (28 March 1896): 7. In the review journal Budapesti Szemle Károly Keleti explicitly compared emigration agents to slave traders, see 'Irányeszmék iparunk érdekében' [Guidelines for our industry], Budapesti Szemle 55:139 (1888): 1-26, here 10; while the "literary and social" daily Fóvárosi Lapok characterises the activity of emigration agents as "not much nicer" than slave trade, see 'Kivándorlás' [Emigration], Fövárosi Lapok 30:205 (27 July 1893): 1660. I 1913, the popular weekly Vasárnapi Újság reviewed Alexander Irvine's 1911 novel The Magyar, A Story of the Social Revolution, a novel based on Irvine's undercover experience working with Southern and Eastern European immigrants in Alabama, "which reveals with dramatic force and terribly true colors the horrors that emigrants take part in on the modern slave colonies of the Southern states." The reviewer suggests that the novel should be circulated with governmental support in every country where emigration is a problematic issue. See Szbi, 'Angol regény a magyar kivándorlásról' [English novel about Hungarian emigration], Vasárnapi Újság 60:7 (1913): 135.
} 
network directed and controlled overseas emigration, but also as an agent of communication: the urban press, inseparable from the constantly transforming urban space, was a key agent in the transmission of knowledge and forming public opinion about the emigration question that was in the centre of political, social and cultural discourse in this period.

The urban press is an important source in reconstructing public discourse, and this article is going to rely on newspaper and periodical articles from the late nineteenth and twentieth century periodicals to reflect on the agency of the press in representing emigration, emigration agents in particular. Stories about emigration agents provide a new angle in the study of the emigration process and its changing image in the lands of the Habsburg Empire, as shown by Tara Zahra in her study of a trial of emigration agents in Galicia at the end of the nineteenth century. ${ }^{5}$ Emigration agents feature regularly in the personal recollections of migrants as well in existing studies of the history of Hungarian transatlantic migration; ${ }^{6}$ a more systematic analysis of their representation of their character as individuals and as a group in the press as well as the examination of the agency of the press in using these stories to influence public opinion provides a new perspective on the history of migration.

From the 1880s onwards, articles about - primarily against - emigration became a popular genre in Hungarian newspapers and periodicals, though one should not ignore the fact that the government - initially - did not restrict free emigration, though in 1881 it passed a bill regulating the activities of emigration agents, restricting their operations by requiring them to have a permit and persecuted those

\footnotetext{
${ }^{5}$ Tara Zahra, 'Travel Agents on Trial: Policing Mobility in East Central Europe, 1889-1989', Past and Present 223:1 (2014), 161-193. doi: 10.1093/pastj/gtu002. See also her upcoming Great Departure: Mass Migration from Eastern Europe and the Making of the Free World, (New Zork 2016).

${ }^{6}$ Such testimonials and documents, reflecting experiences not unlike the case of Károly Botond discussed in the introduction, are collected in the volume Ferenc Dániel and István Orosz, $A h$, Amerika! Dokumentumok a kivándorlásról, 1896-1914 [Ah, America! Documents about emigration, 1896-1914] (Budapest 1988).
} 
who acted without. ${ }^{7}$ This was done to pacify some landowners and county authorities who bemoaned the loss of workers in agriculture. ${ }^{8}$ This is reflected in analytical studies published in more 'serious', scholarly and professional publications, which treated migration as a social phenomenon deserving attention, the conflicts it caused notwithstanding - or exactly because of those. ${ }^{9}$ Many of the popular and widely circulated national papers and locally published ones in the country, including political newspapers, satirical and popular magazines, presented a rather different, more simplistic and in their simplicity much more negative and damning agenda in representing various aspects of transatlantic emigration, even when they were supporting government policy. This is well illustrated by the discussion of emigration agents: in their efforts to show the government efforts to regulate agencies in a positive light, the articles have a tendency to present the activities of agents in general (at least those not approved by the government) as evil money-making schemes to defraud poor peasants through feeding them dreamy stories about getting rich in America. ${ }^{10}$

\footnotetext{
7 The more rigid regulations that followed in 1903 when the Hungarian government made an agreement with Cunard will be discussed later.

${ }^{8}$ Julianna Puskás, From Hungary to the United States (1880-1914) (Budapest 1982).

${ }^{9}$ These include the social science journal Huszadik Század [Twentieth Century]; Közgazdasági Szemle [Economic Review]; and the literary review journal Budapesti Szemle. Many contemporary experts of migration, including Gusztáv Thirring, Lóránd Hegedűs, and Sándor Tonelli published in these journals, though motivated by contrasting agendas and armed with different methodologies. See, for instance, Gusztáv Thirring, 'A magyarok kivándorlása Amerikába' [Emigration of the Hungarians to America], Közgazdasági Szemle 20 (1896): 30-52; Lóránd Hegedüs, ’A magyarok kivándorlása Amerikába' [The emigration of Hungarians to America] Budapesti Szemle (1899): offprint; János Farahó, 'Magyar kivándorlók Canadában és Romániában' [Hungarian Emigrants in Canada and Romania], Közgazdasági Szemle 26 (1902): 810-826; H. L. 'Kivándorlás' [Emigration], Közgazdasági Szemle 28 (1902): 798-799; Sándor Tonelli, 'Utazás a magyar kivándorlókkal Amerikába' [Traveling with the Hungarian Emigrants to America], Közgazdasági Szemle 33 (1908): 427-444.

${ }^{10}$ Even if some acknowledge that although emigration agents have a great role in facilitating emigrations, in a great number of cases bad living and earning conditions in the home country should rather be blamed. See Lóránd Hegedűs, 'Kivándorlás' [Emigration], Közgazdasági Szemle 28 (1902): 798. The article in question is a review of two books published on the question of emigration in the same year; Hegedüs argues with a Fiume-based author, Jenő Hegyi, who claimed that the majority of emigrants were taken from Hungary by agents, and $30 \%$ would emigrate even if they had to pay no taxes and could live without any hardship. Cf. Jenő Hegyi, A magyarországi kivándorlás állapota és rendezése, Fiume 1902, 48.
} 
The examination of the treatment and representation of emigration agents in the urban press provides a new angle to the study of mass emigration from Hungary, which is considered an essentially rural movement, since it consisted of large groups of agricultural workers during the large-scale overseas emigration period from Hungary between the 1880 s and the beginning of World War I. ${ }^{11}$ Press reports, especially in larger newspapers circulated to a wider urban audience in the capital and across the countryside had an important role in forming public opinion about questions of transatlantic migration: the articles and their writers provided information, satisfied curiosity, heightened as well as soothed anxieties, and in this process the city was an important agent - and urban space a fertile ground - of communication. ${ }^{12}$ The central role of the urban press - and especially that of the Budapest press - is especially relevant since the centers of Hungarian emigration, in the Northeast and in the South of Hungary, fell outside of the pull of the capital city. Due to its centrality in terms of the governmental and legal regulation of emigration and in the production of the national news cycle, Budapest and the urban press were important agents of knowledge production and transfer in terms of migration. Not only did they inform their readers in cities and the countryside about practical information and the changing legal framework of transatlantic migration, transmitting information regulated and provided by the government, but they also circulated knowledge on the level of personal experiences and stories by migrants themselves, in

\footnotetext{
${ }^{11}$ The agricultural nature of this historical stage of migration in the region notwithstanding, one should be careful not to assume that the migrants were a socially homogenic group. Julianna Puskás, 'Some Results of my Research on the Transatlantic Emigration from Hungary on the Basis of Macro- and Micro-Analysis', in: Julianna Puskás (ed), Overseas Migration from East-Central and Southeastern Europe 1880-1940 (Budapest 1990) 43-58, here 47.

${ }^{12}$ On the relationship of printing, the press and the development of urban space and communication through history, see, for instance, Elizabeth Eisenstein, The printing press as an agent of change: communications and cultural transformations in early modern Europe (Cambridge 1979); Lucien Febvre and Henri-Jean Martin, The Coming of the Book: The Impact of Printing 1450-1800 (London 1976); Jürgen Habermas, The Structural Transformation of the Public Sphere: An Inquiry into a category of Bourgeois Society (Cambridge 1989).
} 
turn encouraging and discouraging their readers to consider and reconsider leaving their homeland.

Daily and weekly papers in the countryside were also aware of the interest of their readers in questions of emigration, and this is especially significant in counties where the number of emigrants did not lessen despite the efforts of the government and the landowning class, who were concerned about losing a mass of cheap agricultural labour. ${ }^{13}$ For instance, in the counties of Tolna and Baranya in the southeastern regions of Transdanubia, newspapers published stories and analyses on emigration quite regularly, at times on a weekly basis, in local centres like Pécs, Szekszárd or Kaposvár. ${ }^{14}$ Despite the often deterrent and intimidating tone of the articles, however, the number of emigrants show that they were not successful, and it appears that stories about the miserable victims of emigration agents "of dubious reputation" were often in vain. ${ }^{15}$

\section{Emigration Agents in the Press}

For many papers, to represent emigration as a destructive force was a main element of the nationalist agenda, reflecting a concern expressed by the authorities and landowners in certain regions caused by the loss of population. Among the many types of press publication, three were the most visible and effective in influencing public opinion; the biggest, most popular ones were produced in Budapest, but their power (and power of persuasion) went well beyond the capital. Consequently, the role

\footnotetext{
${ }^{13}$ Julianna Puskás, From Hungary to the United States (1880-1914) (Budapest 1982) 110. Ferenc Szili, Kivándorlás a Délkelet-Dunántúlról Horvát-Szlavónországba és Amerikába 1860-1914 [Emigration from Southeastern Transdanubia to Croatia-Slavonia and America, 1860-1914] (Kaposvár 1995) 243288.

${ }^{14}$ Szili, Emigration from Southeastern Transdanubia, 243-288.

${ }^{15}$ Szili, Emigration from the Southeastern Transdanubia, 279.
} 
of the political newspaper, the satirical magazine, and the encyclopedic weekly cannot and should not be underestimated as agents of production and circulation when it comes to informing the public about emigration. The image they created and presented of the emigration agent, who became a central figure of the emigration process and owes his image of a storybook villain of the story of emigration is undeniably powerful - not only on a personal level of the individual migrants but also in collective memory. ${ }^{16}$

Due to the controversial character of their activities, emigration agents received a lot of attention in the press throughout the Habsburg Monarchy; the papers, sensing the potential of increasing public notice, used the opportunities provided by the scandalous dealings of the agents to publish stories that stirred public interest and at the same time provided opportunities to reflect on wider social and political issues in the Habsburg Empire. In turn, the news and reporting on emigration agents did not only warn readers of the dangers of emigration, but could even become a tool of dissuading the population of Hungary and other parts of the Monarchy from emigrating in the hands of the government, who could rely on the press reports and at the same time use the press to further the agenda of anti-emigration. Tara Zahra uses the case of a sensational trial of several emigration agents operating in the Galician town of Wadowice, 'accused of seducing emigrants into abandoning their homeland with false promises of American riches' ${ }^{17}$ to illustrate that though late nineteenthcentury popular opinion held that emigration agents held much responsibility for the rapidly expanding emigration rates, their role in the process was inflated, and the negative discourse around the agents was merely one aspect of a growing, complex

\footnotetext{
16 The emigration agent also appears as a character in fiction, including a short story of the popular author Kálmán Mikszáth (in the posthumously published short story collection Töviskes látogatóban [Töviskes visits], Budapest 1912), or in an adventure novel aimed at young readers by István Sárándy (Titokzatos vizeken [On mysterious waters], Budapest 1912).

${ }^{17}$ Zahra, 'Travel Agents on Trial', 161.
} 
set of anxieties about emigration from the Habsburg Monarchy, which could not be halted by putting the agents on trial.

At the same time, Zahra also draws attention to the nationalist character of the increasing anti-emigration stance of the Hungarian government towards the end of the nineteenth century, claiming that 'the Hungarian government, which functioned much like a nation state within a multinational empire, facilitated the emigration of Slovak-, Croatian- and German-speakers, while hindering the departure of Magyar-speakers through bureaucratic channels', using restrictive emigration policy as "a means to construct a more homogenous state in Hungary. ${ }^{18}$ The situation was somewhat more complex, though it is indeed true that two thirds of emigrants from Hungary were not ethnically Hungarian, while they comprised about half of the country's population at the turn of the century. Magyars, together with Slovaks, were the two largest groups arriving in the United States from the Kingdom of Hungary before 1914, even if ' $[\mathrm{t}]$ he ratio of non-Magyars was higher than the proportion they comprised of in the country's total population'. ${ }^{19}$ Moreover, the multicultural character of the emigration process in the period from the 1880s to the beginning of World War I shows that the angle of nationalism that was recurrent in the press, bemoaning the loss of masses of Magyars, was more of an effective slogan than an accurate representation of the facts. ${ }^{20}$ Press reports did not ignore the national question embedded in the emigration process, and warned their readers about protecting the interests of the country. One article complained about the loss of 'the people of Hungary [...] the nation was, but is not. Where has it disappeared to? It died of misery or - emigrated. ${ }^{21}$ Nonetheless, the presentation of emigration agents, even if they are often described as foreigners in the

\footnotetext{
${ }^{18}$ Zahra, 'Travel Agents on Trial', 170.

${ }^{19}$ Puskás, Overseas Migraion, 49.

${ }^{20}$ Puskás, From Hungary to the United States, 115.

21 'Népfogyatkozás Magyarországon' [Population eclipse in Hungary], Pesti Hírlap 69 (1881): 1
} 
Hungarian press, was used to warn against the dangers of the emigration process, and remind the reader of the victims, often innocent peasants hailing from various regions and ethnicities of Hungary. These descriptions are not only 'othering' the emigration agent as a foreigner: they can have implicit of explicit anti-Semitic character. In one instance, for example, emigration agents are described as 'wondering pedlars', ${ }^{22}$ a distinctly Jewish trope, who roam around the country looking for impoverished youth to convince them to emigrate and by offering them an advance loan of travel costs, push their clients debt even before they left Hungary. ${ }^{23}$

The popular press reacted quite swiftly when in 1881, the minister of interior presented the Parliament with a bill to restrict emigration agencies, blaming mass emigration on the nefarious activities of "certain agents and speculators" who convinced their clients, prospective emigrants, to leave the country. ${ }^{24}$ The satirical weekly Borsszem Jankó [named after the Hungarian version of the fairy tale character Tom Thumb], which had been linked to the Liberal Party of Kálmán Tisza even before they came to power in 1875 , did not always miss the opportunity to satirise the governmental agenda if it had the chance. ${ }^{25}$ Even though the publication numbers and readership of the satirical press fell greatly in numbers during the Tisza-era, Borsszem Jankó remained the most influential one, and it wasted no time in parodying the bill restricting emigration agents. Its occasional allegiance with the government had never

\footnotetext{
${ }^{22}$ P. H., 'A kivándorlás Amerikába' [Emigration to America], Világ-Krónika 52:423 (1882), 1.

${ }^{23}$ Tara Zahra also points out that the Wadowice trial and in general the presentation of emigration agents in the Habsburg press had a distinctly anti-Semitic character. Zahra, 'Travel Agents on Trial', 173, 178.

${ }^{24}$ Puskás, From Hungary to the United States, 93-95. On the 1881 legislation, see also Balázs Pálvölgyi, 'A kivándorlás kezelésének megközelítései Magyarországon 1881 és 1914 között' [Approaches to the treatment of emigration in Hungary between 1881 and 1914], in: Katalin Szoboszlai-Kiss and Gergely Deli (eds), A határrendörségtöl a földreformig: Tanulmányok a 70 éves Bihari Mihály tiszteletére (Györ 2013) 399-402. The bill, as accepted by the Parliament, is available online as "1881. évi XXXVIII. Törvénycikk a kivándorlási ügynökségekről” [Statute XXXVIII of 1881 on emigration agencies], http://www.1000ev.hu/index.php?a=3\&param=5995 [last accessed 20 April 2014l.

${ }^{25}$ Domokos Kosáry and Béla G. Németh. A magyar sajtó története. [The History of the Hungarian Press] (Budapest 1985), II-2-394.
} 
deterred the journal from mocking its actions; and moreover, as noted earlier, the government did not intend the bill to restrict emigration, but rather the activities of emigration agents to protect the interests - in the form of agricultural workers - of the landlords. Published on 8 May 1881, Borsszem Jankó's alternative proposal for a 'law to eliminate emigration' favoured 'humane methods' to prevent emigration, instead of the 'draconian rules that the government is planning'. Identifying the "cause of emigration" in "the lack of welfare," the satirical proposal intends that the bad conditions should turn out well - and lead to welfare. ${ }^{26}$ This shows an awareness of the conditions of agricultural workers in the rural areas, who were generally the easiest 'victims' of emigration agents to be enticed with the promises of better working conditions and higher wages.

Among the suggestions of the satirical journal's proposed law is a government office where they would bribe prospective emigrants not to leave the country; providing them with a "house with as many floors as the number of children they have" and for those who would prefer land to a house, a plot of land with a drainage system flowing with milk and honey, "straight out of the land register of Canaan." For emigrants for whom bribe is not enough and more forceful methods are necessary, "a cordon of young ballerinas will be erected on the country border, enticing emigrants to return using seductive dances and movements;" and road signs on the border will be upside down "so that when the emigrants lose their way, they would return to the bosom of the homeland (said bosoms will be filled with fresh milk in order to enlarge their attractiveness)." Moreover, along the ballerinas, there will be another cordon, lined with young performers whose task will be to recite special poems in order "to soften the hearts of the emigrants and seduce them back to our poor homeland," such

\footnotetext{
26 “Törvényjavasjat a kivándorlás megszüntetésére. Beadja Irányi Dániel” [Proposed law to eliminate emigration, Submitted by Dániel Irányi], Borsszem Jankó, 14 (8 May 1881): 5.
} 
as the poem "The traveler looks back from Vienna," and the one that starts with the line "If I return home happier." Not only to feed the emigrants' spirit, beer taps would also be set up along the border, where they would be given enough to drink themselves under the table to be transported back to the homeland "wrapped in sheets.”

What the satire in Borsszem Jankó does not address is the question of emigration agents, who were in the centre of attention - thanks to the government, who restricted agents' activities in order to disarm some counties' demands for the restriction or even prohibition of emigration. ${ }^{27}$ The urban press reported various methods used by immigration agents, urging their readers not to fall victims to unlicensed individuals. They also issued a subtle warning that the dangers of emigration, or more closely, losing one's life savings to avaricious agents coming from or acting in cities ranging from Kassa (Kosice, today Slovakia) to Budapest, Vienna to New York, 'exploiting emigrants by all kinds of ruthless methods. ${ }^{28}$ These warnings occasionally came in the form of stories of disappointment told by unsuccessful of returnee emigrants. In one case an illegally working emigration agent convinced a few inhabitants of a village near Szatmár [Satu Mare, today Romania] to sell everything they owned and in exchange for the money he would smuggle them out of the country. They were caught as early as Szatmár station, but the story would serve as a warning against illegal methods of emigration, and trusting shady agent characters especially. ${ }^{29}$ Others, who could not make their fortune in America, such as the case of 30 emigrants from Zemplén county, who could not make enough money

\footnotetext{
${ }^{27}$ Puskás, From Hungary to the United States, 96.

28 'A magyarok kivándorlása Amerikába' [The emigration of Hungarians to America, Vasárnapi Újság 46:34 (1899): 570.

29 ‘A kivándorlási szédelgés’ [The emigration dizziness], Gazdák Lapja 2:40-44 (October 1903): 5.
} 
thanks to the nature of the local labour market and ongoing strikes, were forced to return home 'rich in experience, but with empty pockets' ${ }^{30}$

The Országos Hírlap [National Newspaper], the short-lived venture of the writer Kálmán Mikszáth to publish a liberal newspaper independent from political or business influences, was edited and produced in Budapest and aimed at a countrywide readership, published several such warning stories over its brief run of two years between 1897 and 1899. ${ }^{31}$ The emigration-themed articles cover many topics, and the coverage of emigration agents go from lone swindlers to international agencies, whose victims are innocent peasants from the Hungarian countryside. For instance, one report on 'Swindled emigrants' in 1898 was concerned with the case of Tamás Boné, János Kosztka, Pál Alext and Adolf Huber,

'a quartet of swindlers whose game was to prevent emigration. The quartet hindered people wishing to go abroad by taking away all their possessions at the Budapest railway stations, gave them third-class tickets to Vienna, and told them to look for some gentlemen "with red stars" who would be waiting from them in Vienna. The starred gentlemen, who were in fact the agents of the Miszler [sic]-agency in Vienna, ${ }^{32}$ would not even talk to the deceived emigrants, since the agency had no official connection to the quartet of swindlers in Budapest. The four were duly reported to the police in Budapest, and were captured. As they had previous criminal convictions, and Boné is permanently banned from the capital, they will be staying in prison for a while.' 33

The fact that the crooks tried to imitate the existing network of local offices of the cities en route shows that the system of loosely connected local offices functioned and were known well enough to make newly arrived peasants believe and fall for the fraud.

\footnotetext{
30 'Visszajövet Amerikából' [Return From America], Képes Családi Lapok 5 (1880): 80.

${ }^{31}$ For more on the history and background of the newspapers, and the reasons for its lack of success, see Katalin Báthori, Mikszáth Kálmán Országos Hírlapja [Kálmán Mikszáth’s Országos Hírlap], (Szeged 2013) Unpublished Thesis, University of Szeged.

32 The Missler agency, based in Bremen, would also face difficulties a few years later, when the government decided to support emigration from Fiume by the Cunard Line instead of the German companies from German seaports.

33 "Becsapott kivándorlók” [Swindled emigrants], Országos Hírlap, 12 January 1898, 7.
} 


\section{Agents of Prostitution and Other Dangers}

The term 'emigration agent' was used quite loosely at times: in another news story in the Országos Hírlap, a small-town tavern-keeper/procurer was also given the title of emigration agent leading in an article that was mostly about prostituting a young girl in 1898:

'Ferenc Flattinger, a well-off pub owner from Nagybecskerek [today Zrenjanin, Serbia] - as reported by our correspondent - coaxed a girl to Belgrade in the Spring, under the pretense of helping her to find employment. He placed the girl in a house of dubious reputation, from where she could escape only with difficulty. On her arrival home, she made a complaint at the police, where Flattinger was convicted and obliged to pay 20 florins. The sheriff of Torontal county, however, sentenced him to an incarceration for 20 days and a fine of 100 florins on the second degree for unlicensed mediation of emigration. ${ }^{34}$

Flattinger received only a small fine for trying to sell a peasant girl into prostitution, received a much more serious punishment on the grounds of aiding and abetting unlicensed emigration. This may have happened out of the desire to make a statement to discourage such activities in a time when, despite the existing restrictions on the operation of emigration agents in the countryside, many county authorities were in "near panic" because of the growth and spread of emigration in certain regions. ${ }^{35}$

The question of prostitution and its connection to emigration did not go unnoticed by the press, especially from the early twentieth century, and prostitution as a danger for emigrant women - facilitated by the activities by ruthless emigration agents - was addressed in the press with some regularity. Not only does the daily Budapesti Hirlap point out that 'the news has spread in the entire civilized world that Budapest is the main market of international white slave traffic,' it draws attention to the agents of prostitutions, who also act as emigration agents: they recruit women in

\footnotetext{
34 ‘A kivándorlási ügynök’ [The emigration agent], Országos Hírlap, 2 July 1898, 5.

${ }^{35}$ Puskás, From Hungary to the United States, 96.
} 
Budapest, but they also travel around the country, especially to places where emigration is common due to economic hardship - '[w] hen the men of the people leave the land of their birth, how much easier it is to convince women to give credit to the seductive promises and follow the agent to the colorful unknown countries. ${ }^{, 36}$ The efforts of the US to curb immigration were also addressed in the press, several articles warning that it is forbidden to take women to the country with the aim of prostitution 'or any other immoral purpose.' 37

Several reports and congresses problematized prostitution and emigration in terms of each other nationally and internationally. ${ }^{38}$ In 1902, A Hét, primarily a journal of arts and literature, published a long report on a recent congress on prostitution and the white slave trade, warning against 'the loss of Hungarian girls over the country borders'. The report was very critical of the recent efforts of the Ministry of the Interior to curb prostitution, arguing that their discourse was too much focused on the idea of 'morality' rather than offering practical solutions.

\begin{abstract}
'But what will happen if the gendarme on the border intercepts suspicious young women on the way abroad? "Back to morality!" - exclaim the philanthropists, though the reality [for these women] is back to the slough at home. [...] Does it help those poor girls if they cannot leave the country? They would not want to leave if they could stay home. [...] The question of emigration in connection to the white slave trade is the same as with any other trade. [...]. So if they want to help this export, they should not begin at the border, but inside the border. And there they will not touch it, since there the question of the white slave trade is a women's question, and the women's question is simply a men's question.'
\end{abstract}

\footnotetext{
36 ‘A leánykereskedelem’ [White slavery], Budapesti Hírlap 28:153 (1908): 5-6.

37 'A kivándorlás korlátozása' [Curtailing emigration], Pesti Hírlap 29:112 (11 May 1907): 13. See also 'A vándorlások rendőri korlátozása' [The curtailing of migrations by the police], Népszava 35:112 (1907): 2-3.

${ }^{38}$ For instance, Budapesti Hírlap reported on Marcus Braun's findings about human trafficking and Hungarian emigration which claimed that thousands of Hungarian women were sent into prostitution in the United States every year, see 'Az amerikai magyarság pöre' [The lawsuit of American Hungarians], Budapesti Hírlap 25:359 (30 December 1905): 8. For more information on Braun and his report, see Gunther Peck, 'Feminizing White Slavery in the United States: Marcus Braun and the Transnational Trafic in White Bodies, 1890-1910', in: Leon Fink (ed.), Workers Across the Americas: The Transnational Turn in Labor History (Oxford 2011) DOI:10.1093/acprof:oso/9780199731633.003.0017; or Tibor Glant, 'Hungarian-American Relations', Hungarian Studies Review 32:1-2 (2005): 1-13.
} 
The article concludes that as long as women are condemned to slavery at home, at the mercy of men, they should be given protection and independence, or if not, they should be allowed "to die wherever they want." ${ }^{39}$ Unlike the previously quoted article about the tavern keeper who tried to sell (at least) one girl into prostitution and who ultimately received a much stricter punishment for furthering the emigration agenda, it would appear that when it came to organised prostitution, there were voices in the public space who thought prostitution was a more pressing moral issue than emigration. $^{40}$

Prostitution, while a major danger associated with emigration, ${ }^{41}$ was not the only one, and the press published other, similar warnings connecting emigration agents with other dangers of emigration, using the opportunity to warn their readers about the agents' possible misrepresentations of the conditions in the target countries, even though they occasionally had to admit that the conditions in the Hungarian countryside explained the growing number of emigrants. Magyarország, a mediumsized newspaper, and the first evening paper published in Budapest, reported in 1896 that

"[t]he pressures of this winter can be characterised by our correspondent in Fiume, who reports that three hundred emigrants arrived to Fiume on Friday, from where the emigrants will take a Hungarian ship to Genova, and from Genova an Italian ship to Brazil. [...] Another explanation for

\footnotetext{
${ }^{39}$ Tamás Kóbor [Adolf Berman], "Leánykereskedés” [Prostitution], A Hét, 29 June 1902, 414-415.

${ }^{40}$ Prostitution and efforts to control it were increasingly the subject of public discourse in Budapest as well as other parts in the country from the second part of the nineteenth century, prostitution being seen as a threat to order as well as public health. On prostitution in Budapest and Hungary, see Markian Prokopovych, 'Prostution in Budapest in the Late Nineteenth and Early Twentieth Century', in: JeanMichel Chaumont, Magaly Rodrigues Garcia and Paul Servais (eds.), The Kinsie Reports: The League of Nations and Its Investigation into Traffic for Prostitution in the 1920s (Geneva forthcoming); Susan Zimmermann, 'Making a Living from Disgrace: The Politics of Prostitution, 1860-1920', in: Andrea Pető (ed.), CEU History Department Yearbook 1994-1994 (Budapest 1995); Judit Forrai, ‘A 19-20. századi magyar prostitúciópolitika története' [The history of the politics of prostitution in $19-20^{\text {th }}$ century Hungary], Orvostörténeti közlemények 54 (2008): 31-45.

${ }^{41}$ As the Budapesti Hírlap wrote in 1910, several international congresses addressed the problem of preventing prostitution, and it was stated that it would be advisable to internationally coordinate emigration and prostitution legislation. 'A leánykereskedelem ellen' [Against white slavery], Budapesti Hírlap 30:262 (1910): 22.
} 
the exodus might be that Hungarian villages are infested by hordes of soulless emigration agents who are trying to convince them with all kinds of tales to leave the country and to pay the agents' fees." 42

The authorities were sometimes successful in catching unlicensed agents and crooks taking advantage of the people in villages and rural areas. For instance, 'Pinkász Stern' from Ungvár [Uzhhorod, today Ukraine] was sentenced to a month in prison for helping people from Ung country to emigrate without having an agent's permit in 1898. The group he accompanied was detained in Budapest, and although Stern tried to bribe the policeman with five florins, he was additionally sentenced for attempted bribery. ${ }^{43}$ Another case concerned "Oszkár Albersz," an infamous emigration agent active in Upper Hungary [today Slovakia], who was arrested by the German police in Ratibor [today Czech Republic] in 1903. An Austrian agent, 'Albersz' was quite active in Upper Hungary, where he usually appeared dressed in the uniform of a railway officer, impressing the village folk with his attire and his promises of a better future across the Atlantic Ocean. He reportedly earned between 20,000 and 30,000 florins by delivering thousands of emigrants to a shipping companies in Bremen. He was in contact with companies in Bremen and Hamburg, whose tickets he was selling, and he also worked the Kassa-Oderberg train line, where he convinced passengers from Upper Hungary to Brandenbbburg to buy tickets and to exchange Hungarian currency to German. ${ }^{44}$

Some other agents operated by correspondence: according to a newspaper report from 1909, the gendarmerie of Borossebes [Sebiș, Arad county, today Romania] confiscated about sixty letters found at the post office that all encouraged people to emigrate. 'The letters were sent by the Zagreb agency of the Misler [sic] Company in

\footnotetext{
${ }^{42}$ Magyarország, 1896. január 14.

43 'Elítélt kivándorlási ügynök' [Emigration agent sentenced], Országos Hírlap, 2 June 1898, 9.

44 'Elfogott kivándorlási ügynök' [Emigration agent caught], May 1903, Twentieth Century Database http://www.huszadikszazad.hu/bulvar/elfogott-kivandorlasi-ugynok-2435 [last accessed 20 April 2014].
} 
Hamburg. ${ }^{45}$ But letters have arrived to other villages, even to very small ones. [...] The letters use loud promises and very advantageous travel conditions to convince uneducated people to emigrate, of course by the cheapest offer of the Hamburg agency. During the legal proceedings it turned out that an official of the Zagreb agency, who originally hailed from Arad county, wrote most of the letters, because he wanted to earn his commission by enticing his acquaintances to buy tickets. ${ }^{46}$ On the other hand, it appeared from the press that the officials of Zólyom county [Upper Hungary, today Slovakia], was unable to catch the emigration agents active in the county even despite the strictest controls introduced: in 1912, officials were "helpless against foreign agents. The local ispán (county administrator) submitted a report about the practices of the foreign agents to the interior minister and notified the border police." 47

\section{The Role of Shipping Companies}

From the above examples it appears that not only illegally operating or unregistered emigration agents appear in the press as supporting characters of emigration attempts gone wrong, but agents associated with (predominantly German) shipping companies. The Cunard Line, called "Gúnár Lina" [Gander Lina] in folk

\footnotetext{
${ }^{45}$ The in fact Bremen-based Missler agency's name was not only misspelled but its location changed as well in the press report.

46 'Kivándorlásra csábító levelek' [Letters seducing to emigrate], February 1909, Twentieth Century Database,

http://www.huszadikszazad.hu/1909-februar/gazdasag/kivandorlasra-csabito-levelek [last accessed: 20 April 2014]

47 'Kivándorlás titkos utakon' [Emigration on secret roads], 'November 1912, Twentieth Century Database, http://www.huszadikszazad.hu/1912-november/gazdasag/kivandorlas-titkos-utakon [last accessed: 20 April 2014].
} 
language, ${ }^{48}$ the company that was contracted by the Hungarian government to start a Fiume-New York line to transport Hungarian emigrants, is curiously missing from stories of nefarious emigration agents. The temporary contract was signed in 1904, but the line had started already in November 1903. Following the passing of the new emigration laws of 1903 and the treaty with the Cunard Line that gave them the right to transports migrants from Fiume to New York, the emigration policy of the Hungarian government came under attack not only in the Hungarian parliament as well as internationally, but also in the press. ${ }^{49}$ The financial background of emigration was often framed in terms of the shipping companies and their representatives exploiting prospective emigrants in the hope of making extraorbitant profit. The agents of legitimate shipping companies, but especially those operating illegally, were increasingly accused of actively hindering emigrants who wanted to use the services of other companies while also forcing them to use their services - for unreasonable sums of money, of course..$^{50}$

Despite the estimated potential for profit the Hungarian government was expected to make on subsidizing the emigration business to Cunard (provided that they learn from the positive example of the German Lines, as recommended by some analysts ${ }^{51}$ ) the contract was considered controversial, and was severely attacked in the press: not only by the German shipping companies who had enjoyed somewhat of a monopoly in transporting Hungarian emigrants from German ports before, but also by the Hungarian opposition forces. The agitation at home and abroad did not cease as a

\footnotetext{
${ }^{48}$ Emőke Tomsics, 'A "Gúnár Linával” a "nagy vizen”" [With 'Gander Lina' on the 'Great Water'], Hungarian National Museum, http://www.hnm.hu/hu/progr/EventCalendar.php?y=2012\&m=4\&d=16 [last accessed: 20 April 2014].

49 Julianna Puskás, Kivándorló magyarok az Egyesült Államokban 1880-1940 [Emigrating Hungarians in the United States 1880-1940] (Budapest 1982), 136-145.

${ }^{50}$ Puskás, Emigrating Hungarians, 141.

${ }^{51}$ Egan Ede, 'A kivándorlás üzeme és a fiume-newyorki vonal jelentősége' [The business of emigration and the significance of the Fiume-New York line], Mérnökszemle 37:12 (1903): 548-557.
} 
growing number of reports criticised Cunard for a variety of reasons, including the quality of their services and for defrauding emigrants (i.e. being too expensive despite the subsidies). By 1914, the government had to concede that Cunard was unable to handle emigration traffic from Hungary alone and the German companies were not only dominating the Northern seaports, but quite active in the Adriatic as well; moreover, the Hungarian government could not supervise the entire activity in the harbours. ${ }^{52}$

Where some of the Hungarian press had previously supported the government agenda by drawing attention to unapproved agents, some papers now also moved in support of the Cunard contract. Borsszem Jankó had in fact 'predicted' the establishment of the 'Adria Steam Ship Company' in Adrianopolis (the future name of Fiume they proposed) under the leadership of Mór Jókai, the famous writer, journalist, and supporter of Tisza in an article from 1882, but instead of the transatlantic passage of thousands of peasants from northeastern and southern Hungary, they counted on the emigration of Jews to Palestine on a ship to be called 'Jordan' ${ }^{53}$

Vasárnapi Újság, a popular Sunday illustrated weekly, on the other hand, published several flattering accounts of transatlantic travel on the Cunard Line, though it is not clear what class the reporters were travelling on, which may have coloured their perspective. Around the turn of the century, the journal reinvented itself into a literary journal from its previous incarnation of a nationalist vehicle aimed at the urban middle class and the rural gentry, but its readership remained quite wide

\footnotetext{
${ }^{52}$ Puskás, From Hungary to the United States, 98-109.

${ }^{53}$ Advertising flyer of the "ASSC: Adria Steam Ship Company" Borsszem Jankó, 1 January 1882, p. 5. The often strongly anti-Semitic character of Borsszem Jankó has a more complex background in that many of the editors and the staff were from the assimilated Jewish middle-class and their satire was often aimed at non-assimilated Jews. For more on this, see Mary Gluck, 'Jewish Humor and Popular Culture in Fin-de-Siècle Budapest', Austrian History Yearbook 39 (2008): 1-22. doi: $10.1017 /$ S0667237808000023
} 
and robust. ${ }^{54}$ In his account of his own passage in 1903, published as a series of journalist Emil Zerkowitz ${ }^{55}$ gives a very positive description of the ship Ultonia and the journey from Fiume to New York, even if he laments the necessity of emigration and the sad events leading to it. ${ }^{56}$ Reporting from Naples, he writes about 'the emigrant victims of the soulless emigration agents' and the damage the agents cause to 'all the pitiful people'. The new emigration law, he writes hopefully, would limit the number and the activities of emigration agents, pay more attention to the migration movements, and hopefully also lessen the numbers of emigrants. His support of the government initiative in fact goes as far as lamenting that too few people are using Cunard: this to him is attributed to the machinations of the other companies, but he expresses hope that the government would intervene. After all, the Cunard ship was a lot faster and the view of the Sicilian coast was beautiful, not to speak about the North African coast and Gibraltar, which makes his report read somewhat like the brochure of a travel agent. ${ }^{57} \mathrm{He}$ finishes his series of reports with the assertion that 'now at least there is control and protection from the government' ${ }^{58}$ The safety of the emigrants was a central element of the government-friendly discourse of the newspapers, the main message being that ' $[t]$ he Hungarian government made a contract with a big steamship company, the Cunard Line, mainly

\footnotetext{
${ }^{54}$ Kosáry and Németh, History of the Hungarian Press, II/443-448.

${ }^{55}$ A few years later, in 1907, Zerkowitz took up the post of Hungarian consul overseeing immigration in New York, and in the 1920s he was the Hungarian ambassador in New York. For a fuller biography and his connections to the USA, see his biography: http://www.zerkovitz.hu/z emil.htm.

${ }^{56}$ His description differs significantly in method and style from the article of Sándor Tonelli, who also made a journey on the Ultonia a few years later, in 1907, and wrote about his experience and encounters with passangers in the lower decks, accompanied with photographs, in Vasárnapi Újság in 1908. See Tonelli, 'Magyarok a nagy vizen' [Hungarians on the great water], Vasárnapi Újság 55:9 (1908): 173-175. He later published sociological studies based on his experience, e.g. Traveling with the Hungarian Emigrants to America, as well as the monograph 'Ultonia. Egy kivándorló hajó története' [Ultonia. The story of an emigrant ship] (Budapest 1929).

57 Zerkowitz Emil, 'Új vonal Fiume és New York között. Jelentés Fiuméböl, 1903. November 17.' [New line between Fiume and New York. Report from Naples, 17 November 1903.], Vasárnapi Újság, 50:48 (1903): 797-798.

${ }^{58}$ Zerkowitz Emil. 'Fiumetol New Yorkig' [From Fiume to New York], Vasárnapi Újság, 51:31 (1904): 529-530.
} 
in order to ensure that those miserable people who hope to make their future in another land would not be subjected to the plunder of traffickers', ${ }^{59}$ even when other publications made clear that 'the wise government' was profiting 'approximately fifty-five crowns per capita on their contract with Cunard' ${ }^{60}$

\section{The Role and Representation of the Capital City as a Hub and Agent of Migration}

Studying the urban press of the late nineteenth and early twentieth century shows that while the centrality of Budapest was not so clear in the public discourse of emigration at the time, it was a vital hub of emigration movements in terms of railroad connection, information network, the location of central authorities and their agencies that attempted to control and restrict the outflow of emigration overseas as well as shipping companies that facilitated it. In his 1911 article on Budapest's American emigration in the iconic literary and review journal Nyugat, ${ }^{61}$ the statistician Miklós Móricz (1886-1966) ${ }^{62}$ emphasizes the role of Budapest in the emigration network domestically and internationally, positing that American emigration from the Hungarian capital city was 'a new stage of development, and perhaps the link that will connect it to the net of metropolises. ${ }^{63}$ His article on the

\footnotetext{
59 “A kivándorlók biztonságos utazása” [The safe travel of the emigrants], June 1904, Twentieth Century Database, http://www.huszadikszazad.hu/1904-junius/bulvar/a-kivandorlok-biztonsagosutazasa [last accessed: 20 April 2014].

60 "A Cunard line és a magyar kivándorlók" [The Cunard Line and the Hungarian emigrants], September 1904, Twentieth Century Database, http://www.huszadikszazad.hu/1904szeptember/gazdasag/a-cunard-line-es-a-magyar-kivandorlok [last accessed: 20 April 2014].

${ }^{61}$ Miklós Móricz, 'Budapest amerikai kivándorlása' [Budapest's American emigration], Nyugat 4:1 (1911) 100-107. Online verson in the Electronic Periodical Database of the Hungarian National Library: http://epa.oszk.hu/00000/00022/00071/02118.htm [last accessed 20 April 2014].

${ }^{62}$ A law student in the 1900s, Móricz was also working as a journalist at a number of Budapest newspapers, writing smaller news articles, and publishing longer articles in scholarly journals. For Móricz's work as a statistician, see Iván Kápolnai, ‘A statisztikus Móricz Miklós' [The statistician Miklós Móricz], Statisztikai Szemle 86:2 (2008): 165-184.

${ }^{63}$ Móricz, 'Budapest's American emigration' http://epa.oszk.hu/00000/00022/00071/02118.htm. There is a rich public discourse among contemporaries regarding the difference between Budapest and Western cities and whether - and how - this can be overcome. For a discussion of aspects of the
} 
emigration of the Budapest population to America, which reflected the latest methods and results of statistical analysis, was also a balanced and rather poetic discussion of Hungarian emigration to America. ${ }^{64}$

Móricz connected the process of migration from rural areas to the city to the migration of Hungarian peasants to the United States, arguing that 'for the Hungarian peasant, the cities of the United States are almost closer than Budapest itself; and especially in the last few years it appears as if the urbanisation of the Hungarian peasantry happened through the cities of the United States. In these years, Budapest closed itself off from the countryside.' The concept of migration, he argues further, has changed to include a meaning of changing places within culture: the American emigration of the Budapest population has given the idea that migration, like all other processes of life, is subject to development. 'Unlike us,' writes Móricz, 'North America represents the city, that is, the cultural degree of the city, and the inhabitants of Budapest are migrating there.' In Móricz's model, Hungary had only one real city, Budapest, and thus the majority of the Hungarian population were 'scattered on the levels that connect the ancient state with the first degree of civilisation: the village, and on those connecting the village with the city.' Since Budapest is to him on a higher level of civilisation, a place where one can scarcely find people from levels lower than that of the village, the city is not suitable to accept such elements of the population or to educate them further; thus, they are the ones who eventually leave Budapest to seek fortune overseas, in the 'North America Union that in contrast to us means the city, the cultural peak of the city'. They are villagers, who are en route, for

'peripheral modernization' of Budapest, see, for instance, Maciej Janowski, 'A Capital in the Periphery. The Developmental Specificity of Budapest (As a Big East Central European City)', Acta Poloniae Historica 111: The Specificity of Historical Development: East Central Europe in the Nineteenth and Twentieth Century (2015): 141-166.

${ }^{64}$ The article was published in Nyugat, the journal that consciously went against the conservative and academic literary tradition of the early twentieth century, and whose contributors included the literary elite of the capital city and the country. Moreover, its contributors had more liberty to publish articles not strictly in line with the official government policy on emigration. 
a month or two, a year, one lifetime; almost city-dwellers, born as such or raised by the city, not always the same, but they are headed to a city all the same. ${ }^{65}$

According to the official statistical calculations that Móricz presents and analyses in the article, between the years 1902 and 1909, Budapest lost less than half percent of its population to emigration. Based on these numbers, he writes, many have grown to accept a fictional statement as the truth: they claim that the capital city is full, it does not need more new elements to become a proper city, and 'now the emigrant population of the country is indeed forced to go to the United States.' $\mathrm{He}$ draws attention, however, to the boom of the city population following the turn of the century as well as the complexity of demographic statistics. Unlike the overwhelming amount of articles in the Hungarian press that tend to present emigration as the cause and effect of the destruction of the nation, its economy and culture, Móricz considers emigration as a necessary, and not necessarily negative, social process. He does allow, however, that as a result of emigration, 'the life of the capital city suffers from many diseases; [...] but emigration to America will now remain a constant phenomenon, but we still do not know if it will be a sign of illness or of health. ${ }^{96}$

It is clear from Móricz's article that Budapest was in no such danger; however, due to its central position in the processes and movements of Hungarian transatlantic migration and to the nature of the Hungarian press in the nineteenth and the twentieth century, Budapest does have an agency in the representation of Hungarian migration. Crucially, it was the centre of the often critical press and its urban audience that shaped public opinion on the issue. The centrality of Budapest in

\footnotetext{
${ }^{65}$ Móricz himself was the personally familiar with the model described in his study: his father was the hardworking small peasant who had been to America and then back to his village, whereas Miklós and his brother Zsigmond, one of the most well-known writers and publicists of the early twentieth century, were educated and remained in the city. The writings of both brothers, whether statistical of literary, show an interest in and commitment to represent and give a voice to the peasantry and the difficulties faced by the poor population of the countryside.

${ }^{66}$ Móricz, ‘Budapest’s American emigration’ http://epa.oszk.hu/00000/00022/00071/02118.htm.
} 
the migration discourse may have been somewhat undermined by the public concern for the rural population that, removed from the pull of the capital city was nonetheless more threatened by mass emigration, and was often presented by the urban press as innocent victims of capitalist exploitation and trickery, which often took place in or came from the city through the agency of emigration agents operating from out of cities, but recruiting mostly in the villages and the countryside. The shipping companies competing in the national market with the government-sponsored Cunard Line were seen as the main protagonists of such exploitation and could even be paralleled with the agents of white slavery network. Voices critical of the prevailing opinion, such as those by Miklós Móritz in his Nyugat article from 1911, which attempted to link emigration to larger problems of the nature of urbanisation in Hungary, the condition of the countryside economy as well as the availability of jobs on offer in the Hungarian capital city, remained among the less heard.

\section{Conclusion}

The 'peasant exodus', that is, the first great wave of East Central European emigration to America starting in the last years of the nineteenth century, consisting of peasants, agricultural workers and artisans of very diverse ethnic and religious background, had two directions: from Europe to America and back. ${ }^{67}$ One should not forget that the return of the emigrants was just as an important theme in the Hungarian press, whether the emigrants returned destitute or made their fortune. Contradictory sentiments and political and cultural agendas were well represented in 'Bazsalikom' [Basil], the award-winning epic poem of extremely dubious quality - written by the

\footnotetext{
${ }^{67}$ Julianna Puskás, "Migráció Kelet-Közép-Európában a 19. és 20. században” [Migration in East Central Europe in the nineteenth and twentieth centuries], Regio Kisebbségtudományi Szemle 2:4 (1991) 1-2.
} 
leading Hungarian poet and literary scholar of the period Zoltan Erdelyi. ${ }^{68}$ The protagonist of the poem, a man known by the last name of Véghy, a 'nice' member of the gentry loses the 'lands inherited from his ancestors', grows to hate his homeland and emigrates to America, where he gains a fortune, but later returns home when called by his former nanny and by the smell of basil (hence the title of the work). Published in three parts in Vasárnapi Újság in 1908, the poem addresses several aspects of the peculiarities of Hungarian emigration, and is a fitting conclusion to how emigration was presented in the press: a poetic and tragic fate for many emigrating Hungarians who have lost their land or their work, and in their desperation are exploited by various agents of emigration while the government does not give tangible support.

'In Fiume the sea is silent' -

Reported our Gazette in old times.

Naturally, as that is the order:

It is silent, until the silence is broken!

But now, that on a lot of country-money

The "Cunard Line" is standing guard on the rift

Where the people are emigrating -

There is no more silence, there is noise and traffic. ${ }^{69}$

This is a poetic reformulation of the nationalist approach to opposing emigration: even those who leave come back to the call of the homeland, but it also draws attention to the fact that emigration could be a lucrative business for some of its facilitators, and emigration agents were an important part of the assembly line of the process of emigration.

\footnotetext{
${ }^{68}$ Erdélyi was a journalist and amateur writer who wrote everything from poetry to drama, novels to operetta librettos, children's plays to monologues 'for young girls'. The poem discussed here was severely criticised by the renowned poet Dezső Kosztolányi in the 21 February 1909 issue of A Hét. The criticism was mainly for the lack of artistic form and value, but in terms of content, the work is quite didactic and stays on the level of simplistic, atavistic notions of a kuruc, gentry-nationalist, antiSemitic value system. See Ernő Szabó, 'Hat lappangó Kosztolanyi-kritika' [Six hidden reviews by Kosztolanyi], Irodalomtörténeti Közlemények 83:1 (1979), 59-61.

${ }^{69}$ Erdélyi Zoltán, “Bazsalikom” [Basil], Part III, Vasárnapi Újság, 55:20 (1908): 398-399.
} 
The urban press provides a diverse and at the same time rather formulaic image of the emigration agent, putting the agency of the individual in a mass movement in a new perspective. The image of the agent as presented by the press shows profit-oriented men exploiting innocent peasants, workers and other lowerclass people, convincing - or at least encouraging - them to leave their homes for an uncertain - and perhaps unlikely - promise of better opportunities and an overall easier life overseas. This image, however, does not necessarily correspond to the certainly more diverse group of actual emigration agents. These agents, operating individually or as part of an organized network, became an important point of contact for emigrants well before reaching the ports or even the first municipal or country border. This importance was picked up by the press, which made good use of sensational or criminal cases concerning emigration agents and the public attention they could attract in order to influence public opinion as well as reflect the increasing efforts of the government to hinder emigration in late nineteenth- and early twentiethcentury Hungary.

Controversy - in this case reporting on the perceived nefarious business and criminal affairs of emigration agents - is a very important factor to consider when it comes to the power of the press in forming public opinion about emigration and its impact of on the individual, the country, or the nation. Newspapers and periodicals provided practical information regarding emigration processes while at the same time also trying to dissuade Hungarians from leaving the country for another continent by putting these faraway lands and the conditions prevailing there in different - closer perspective. The sheer amount and power of information about emigration and emigration agents - drawn from a wide array of sources: from personal experiences of emigrants, from the promises of emigration agents and the promotions of shipping 
companies, from the Hungarian and other governments - reflects the agency of the urban press. The press, as well as the city itself where it is produced, were universally powerful agents of the production and transfer of knowledge about migration, as shown previously by the case studies concerning the activities of emigration agents and the particular ways the press presented them to influence and reflect the changing public discourse to parallel the evolution of emigration policies in Hungary and within the Habsburg Monarchy. The urban press, inseparable from the constantly transforming urban space, was a key agent in the transmission of knowledge and forming public opinion about the emigration question that was in the centre of political, social and cultural discourse in this period. 